\title{
Hygroscopic properties of newly formed ultrafine particles at an urban site surrounded by deciduous forest (Sapporo, northern Japan) during the summer of 2011
}

\author{
J. Jung ${ }^{1, *}$ and K. Kawamura ${ }^{1}$ \\ ${ }^{1}$ Institute of Low Temperature Science, Hokkaido University, Sapporo 060-0819, Japan \\ "now at: Center for Gas Analysis, Korea Research Institute of Standards and Science, Daejeon 305-340, South Korea
}

Correspondence to: K. Kawamura (kawamura@lowtem.hokudai.ac.jp)

Received: 11 March 2014 - Published in Atmos. Chem. Phys. Discuss.: 25 March 2014

Revised: 23 May 2014 - Accepted: 16 June 2014 - Published: 24 July 2014

\begin{abstract}
To investigate the hygroscopic properties of ultrafine particles during new particle formation events, the hygroscopic growth factors of size-segregated atmospheric particles were measured at an urban site in Sapporo, northern Japan, during the summer of 2011. The hygroscopic growth factor at $85 \%$ relative humidity $[g(85 \%)]$ of freshly formed nucleation mode particles was 1.11 to 1.28 (average: $1.16 \pm 0.06)$ at a dry particle diameter $\left(D_{\mathrm{p}}\right)$ centered on $20 \mathrm{~nm}$, which is equivalent to 1.17 to $1.35(1.23 \pm 0.06)$ at a dry $D_{\mathrm{p}}$ centered on $100 \mathrm{~nm}$ after considering the Kelvin effect. These values are comparable with those of secondary organic aerosols, suggesting that low-volatility organic vapors are important to the burst of nucleation mode particles. The equivalent $g(85 \%)$ at a dry $D_{\mathrm{p}}$ of $100 \mathrm{~nm}$ for nucleated particles that have grown to Aitken mode sizes (1.24 to 1.34; average: $1.30 \pm 0.04$ ) were slightly higher than those of newly formed nucleation mode particles, suggesting that the growth of freshly formed nucleation mode particles to the Aitken mode size can be subjected to condensation of not only low-volatility organic vapors, but also water-soluble inorganic species. Based on this result, and previous measurement of radiocarbon in aerosols, we suggest that the burst of nucleation mode particles and their subsequent growth were highly affected by biogenic organic emissions at this measurement site, which is surrounded by deciduous forest. Gradual increases in mode diameter after the burst of nucleation mode particles were observed under southerly wind conditions, with a dominant contribution of intermediately hygroscopic particles. However, sharp increases in mode diameter were observed when the wind direction shifted to
\end{abstract}

northwesterly or northeasterly, with a sharp increase in the highly hygroscopic particle fraction of the Aitken mode particles, indicating that the hygroscopic growth factor of newly formed particles is perturbed by the local winds that deliver different air masses to the measurement site.

\section{Introduction}

New particle formation (NPF) in the atmosphere is an important factor governing the radiative forcing of aerosols and cloud formation that frequently occurs globally (Kulmala et al., 2004; Holmes, 2007; Bzdek and Johnston, 2010). Recent direct size-segregated observations of the $<2 \mathrm{~nm}$ particle fraction showed that extremely low-volatile organic compounds affect not only nuclei growth, but also participate in the relatively early stages of NPF (Kulmala et al., 2013; Ehn et al., 2014). Although our understanding of nucleation and the growth of freshly nucleated particles has recently advanced (Hegg and Baker, 2009; Metzger et al., 2010; Zhang, 2010; Zhang et al., 2012), a detailed nucleation mechanism remains ambiguous.

In a suburban area of the Yangtze River delta in China, Gao et al. (2009) showed that sulfuric acid is important for the initiation of NPF. Yue et al. (2010) observed that the condensation and neutralization of sulfuric acid caused the growth of freshly nucleated particles during sulfur-rich periods in urban Beijing, China, whereas organic compounds were responsible for particle growth during sulfur-poor periods. Cheung et al. (2011) reported that freshly nucleated particles at an urban 


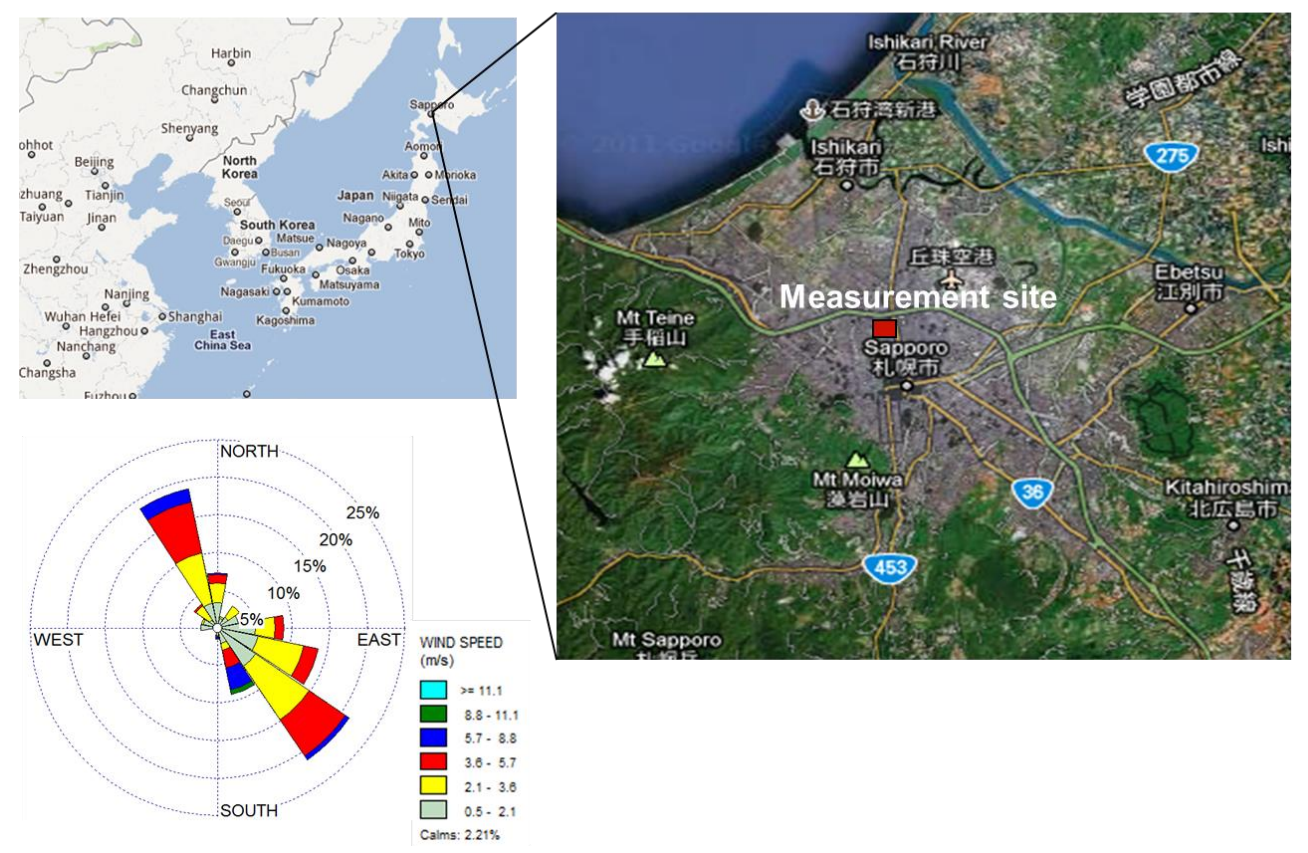

Figure 1. Map showing the measurement site (red rectangle). The measurement site is located on the north campus of Hokkaido University $\left(43^{\circ} 3^{\prime} 56^{\prime \prime} \mathrm{N}, 141^{\circ} 21^{\prime} 27^{\prime \prime} \mathrm{E}\right)$ in the northwest of downtown Sapporo, northern Japan. Observed frequencies of local wind direction with wind speed are also shown.

site in Brisbane, Australia, showed different growth patterns depending on the type of air mass that arrived at the measurement site. However, mechanisms for nucleation and growth of freshly nucleated particles in an urban area surrounded by a deciduous forest remain poorly understood.

As secondary organic aerosols (SOA) and water-soluble inorganic ions such as $\left(\mathrm{NH}_{4}\right)_{2} \mathrm{SO}_{4}$ have different hygroscopic properties, the hygroscopic growth factor $[g(\mathrm{RH})]$ of nucleated particles can be used to infer their chemical compositions. Ehn et al. (2007) measured the $g(\mathrm{RH})$ of freshly nucleated particles and the particle subsequently grown to Aitken mode sizes in a boreal forest in southern Finland. Based on hygroscopic growth measurements of size-segregated atmospheric particles, they observed that the $g(\mathrm{RH})$ values of nucleated particles decreased as particle size increases to the Aitken mode. Ristovski et al. (2010) simultaneously measured the hygroscopicity and volatility of freshly nucleated particles in a eucalypt forest in Australia. They observed that nucleated particles were composed of both sulfates and organics, with the latter exhibiting volatility and hygroscopicity similar to the photo-oxidation products of $\alpha$ pinene. However, the hygroscopic properties of freshly nucleated particles have rarely been studied, especially in an urban area adjacent to a deciduous forest.

Jung et al. (2013) measured particle number size distributions at an urban site in Sapporo, northern Japan, using a scanning mobility particle sizer (SMPS) during the summer of 2011, and discussed the factors controlling the burst of nucleation mode particles and the subsequent growth. As the burst of nucleation mode particles is mainly caused by the growth of nucleated clusters $(<1 \mathrm{~nm})$ into a detectable size $(>3 \mathrm{~nm}$ ), we define particles generated by the burst of nucleation mode particles during the NPF event as freshly formed nucleation mode particles. In this study, we investigate the hygroscopic properties of size-segregated atmospheric particles at the same urban site in northern Japan during the summer of 2011 using a hygroscopicity tandem differential mobility analyzer (H-TDMA) and meteorological parameters. The formation process of the nucleation mode particles during an NPF event was investigated using their hygroscopic growth factors. The subsequent growth of freshly formed nucleation mode particles to the Aitken mode was also investigated using the size-segregated hygroscopic growth factor and meteorological parameters.

\section{Experimental methods}

\subsection{Description of the measurement site}

The hygroscopic properties of ultrafine particles were continuously measured at an urban site in Sapporo between 26 July and 9 August 2011 using an H-TDMA. A map of the measurement site is shown in Fig. 1. The concentrations of total suspended particle (TSP) mass, $\mathrm{O}_{3}, \mathrm{NO}$, and $\mathrm{SO}_{2}$ at the Sapporo observatory near the urban site were obtained from the Ministry of the Environment of Japan (http://soramame.taiki.go.jp/). The times shown in this study are the local time in Japan (LT; GMT + 09:00). 
The city of Sapporo (population 1.9 million, area $1121 \mathrm{~km}^{2}$ ) is located in the western part of Hokkaido, the northernmost main island of Japan (Fig. 1), and is surrounded, except along its northwestern border, by deciduous forest. Our measurement site was located on the north campus of Hokkaido University $\left(43^{\circ} 3^{\prime} 56^{\prime \prime} \mathrm{N}, 141^{\circ} 21^{\prime} 27^{\prime \prime} \mathrm{E}\right)$ in the northwest of downtown Sapporo (Aggarwal and Kawamura, 2009; Kitamori et al., 2009). The campus is surrounded by mainly residential areas, and the urban center is located approximately $2 \mathrm{~km}$ to the south.

Aggarwal and Kawamura (2009) found that photochemical aging was an important factor controlling the watersoluble properties of organic aerosols at the same Sapporo urban site during the spring and early summer of 2005. Agarwal et al. (2010) reported that most of dicarboxylic acids, $\alpha$-dicarbonyls, levoglucosan, water-soluble organic carbon (WSOC), and inorganic ions (i.e., $\mathrm{SO}_{4}^{2-}, \mathrm{NH}_{4}^{+}$, and $\mathrm{K}^{+}$) were abundant in fine particles $\left(\mathrm{PM}_{1.1}\right)$ collected at the Sapporo urban site during the summer of 2005. Using particle size distributions during the summer of 2011, Jung et al. (2013) showed that the burst of nucleation mode particles typically started in the morning (07:00-11:30 LT) at the same urban site, with simultaneous increases in concentrations of $\mathrm{SO}_{2}$, $\mathrm{O}_{3}$, and the UV index under clear weather conditions.

\subsection{Measurement of hygroscopic growth factors of size- segregated ultrafine particles}

The hygroscopic growth factors of size-segregated atmospheric particles were measured using the H-TDMA (Mochida and Kawamura, 2004; Jung et al., 2011). The HTDMA system consisted of an $\mathrm{Am}^{241}$ neutralizer, two differential mobility analyzers (DMAs; TSI, model 3081), an aerosol humidity conditioner (Nafion tubing), and a condensation particle counter (CPC; TSI, model 3010). The sample and sheath flow rates of the two DMAs were set to 0.3 and $3 \mathrm{~L} \mathrm{~min}^{-1}$, respectively. A sample inlet was installed at a height of around $5 \mathrm{~m}$ above ground level. Ambient air was drawn through a $\mathrm{PM}_{1.0}$ cyclone inlet with a flow rate of 16.7 $\mathrm{L} \mathrm{min}^{-1}$. An aliquot $\left(0.3 \mathrm{~L} \mathrm{~min}^{-1}\right)$ of the sampled air was separated and dried to a relative humidity $(\mathrm{RH})$ of less than $5 \%$ using two diffusion dryers before being introduced into the H-TDMA.

The dry mobility diameter selected in the first DMA was increased every $5 \mathrm{~min}$ (six diameters from 20 to $120 \mathrm{~nm}$, with a $20 \mathrm{~nm}$ increment) over a period of $30 \mathrm{~min}$. Dry monodispersed particles classified in the first DMA were then humidified to $85 \% \mathrm{RH}$ using the aerosol humidity conditioner. The size distributions of the resulting particles were measured using the second DMA and the CPC. RH in the sheath flow of the second DMA was maintained at $85 \%$. The residence time of the particles between the aerosol humidity conditioner and second DMA was roughly estimated to be 10 s. All H-TDMA experiments were conducted at sampled air temperatures in the range 287-294 K, and with a mean of $291 \mathrm{~K}$.

The $g(\mathrm{RH})$ of particles is defined as follows:

$g(\mathrm{RH})=D_{\mathrm{p}}(\mathrm{RH}) / D_{\mathrm{p}}(\mathrm{dry})$,

where $D_{\mathrm{p}}($ dry) is the dry particle diameter under $\mathrm{RH}<5 \%$, and $D_{\mathrm{p}}(\mathrm{RH})$ is its diameter at a specific RH. The $g(\mathrm{RH})$ of pure $\left(\mathrm{NH}_{4}\right)_{2} \mathrm{SO}_{4}$ was measured as $1.56 \pm 0.01 \quad(n=3)$ at $85 \% \mathrm{RH}$, which agrees well with the $g(85 \%)$ of 1.56 predicted using the thermodynamic aerosol inorganic model (AIM; Clegg et al., 1998). The predicted $g(\mathrm{RH})$ was calculated by considering the Kelvin effect and assuming a density of $1.76 \mathrm{~g} \mathrm{~cm}^{-3}$ and dynamic shape factor $(\chi)$ of unity for dry particles.

\subsection{Meteorological parameters and air mass backward trajectory}

Meteorological data (temperature, wind speed, wind direction, $\mathrm{RH}$, and rainfall) for the measurement period in Sapporo were obtained from a station located around $2.6 \mathrm{~km}$ south of our study site $\left(43^{\circ} 3^{\prime} 56^{\prime \prime} \mathrm{N}, 141^{\circ} 21^{\prime} 27^{\prime \prime} \mathrm{E} ; 17 \mathrm{~m}\right.$ above ground level) operated by the Japan Meteorological Agency.

The average ambient temperature and $\mathrm{RH}$ were measured as $23 \pm 3{ }^{\circ} \mathrm{C}$ and $72 \pm 11 \%$, respectively. Although most measurements were carried out under clear weather conditions, three rainfall events occurred on 27 July (13:0014:00 LT), 5 August (16:00 LT), and 6 August (16:00 LT). The prevailing local wind directions during the urban campaign varied between southeasterly and northwesterly, with an average wind speed of $3 \pm 2 \mathrm{~m} \mathrm{~s}^{-1}$ (range: $0-11 \mathrm{~m} \mathrm{~s}^{-1}$; Fig. 1).

Air mass backward trajectory analysis can be used to identify the potential source regions and transport pathways of atmospheric particles. Air mass backward trajectories that ended at the measurement site were computed at heights of 200 and $500 \mathrm{~m}$ above ground level using the HYSPLIT (HYbrid Single-Particle Lagrangian Trajectory) backward trajectory analysis method (Draxler and Rolph, 2014; Rolph, 2014). All calculated backward trajectories extended backwards for $96 \mathrm{~h}$, with a $1 \mathrm{~h}$ interval. Errors of up to $20 \%$ of the traveled distance are typical for those trajectories computed from analyzed wind fields (Stohl, 1998). Thus, calculated air mass pathways indicate the general airflow pattern rather than the exact pathway of an air mass.

\section{Results and discussion}

\subsection{Overview of hygroscopic growth factors of size-segregated atmospheric particles}

Figure 2a shows temporal variations in the number concentration of nucleation mode $(7-30 \mathrm{~nm})$ particles $\left(N_{\text {nuc }}\right)$ and 


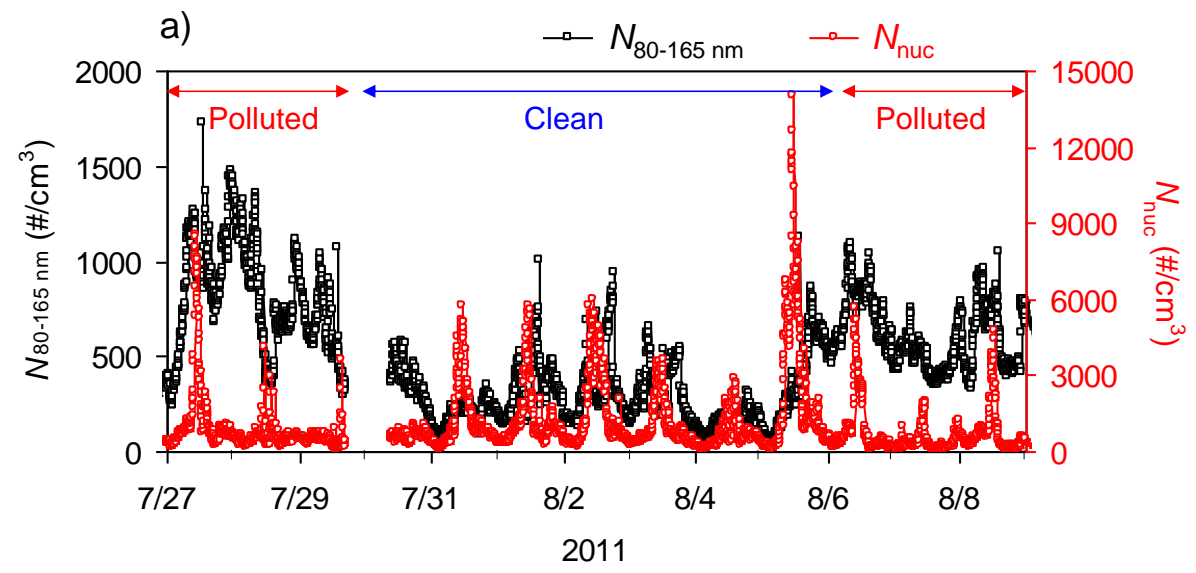

b) July 27-29 and August 6-8 (Polluted)

c) July 30-August 5 (Clean)
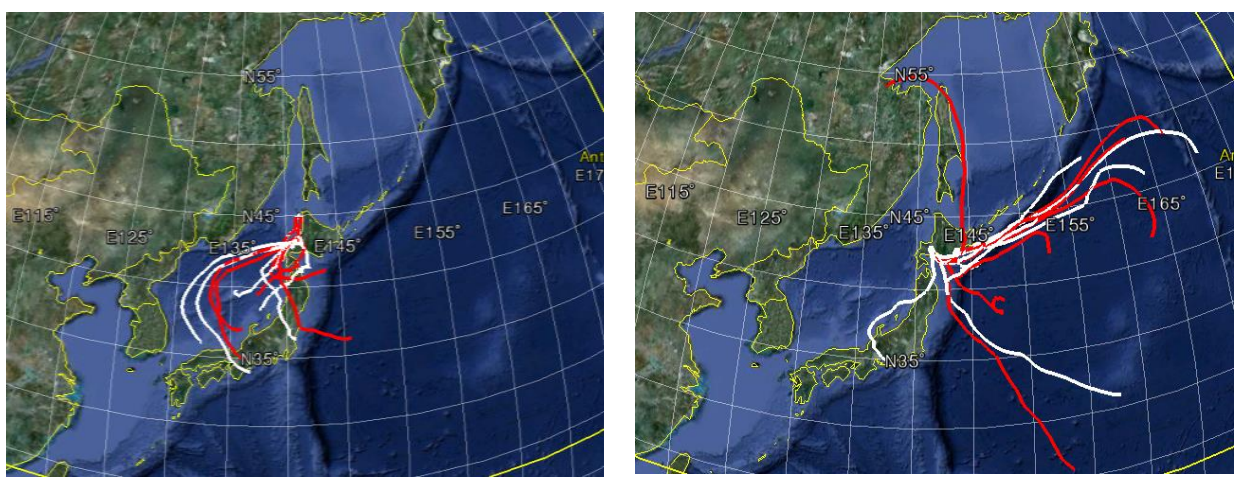

d) July 27-29 and August 6-8

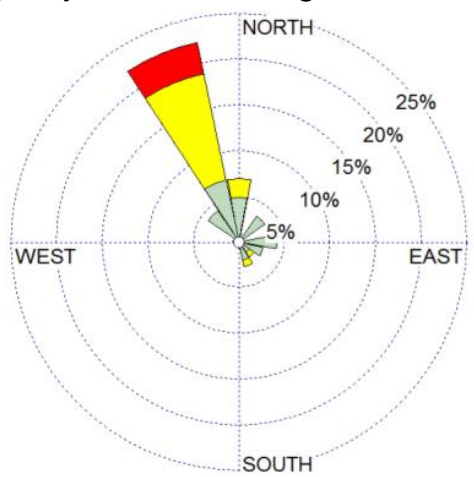

e) July 30-August 5

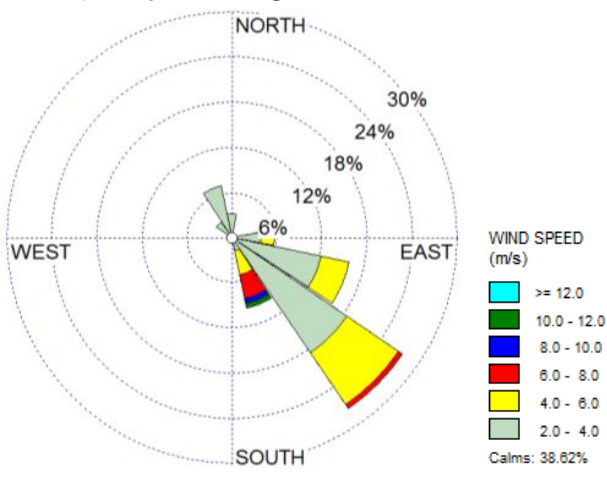

Figure 2. (a) Integrated number concentrations of particles from 80 to $165 \mathrm{~nm}\left(N_{80-165 \mathrm{~nm}}\right)$ and number concentrations of nucleation mode $(7-30 \mathrm{~nm})$ particles $\left(N_{\text {nuc }}\right)$ during the entire measurement period, air mass backward trajectories arriving at the urban site, and observed frequencies of local wind direction with wind speed during the polluted periods (b) 27-29 July and (d) 6-8 August 2011, and the clean period (c, e) 30 July-5 August. White and red trajectories in (b) and (c) represent air mass trajectories arriving at heights of 200 and $500 \mathrm{~m}$, respectively, above ground level.

large Aitken to small accumulation mode $(80-165 \mathrm{~nm})$ particles $\left(N_{80-165 \mathrm{~nm}}\right)$ during the period between 27 July and 8 August. Elevated $N_{\text {nuc }}$ were frequently observed during the entire measurement period. However, different temporal evolutions were obtained for $N_{80}-165 \mathrm{~nm}$ with peaks during polluted periods (27-29 July and 6-8 August). $N_{80-165 \mathrm{~nm}}$ ranged from 240 to 1700 particles $\mathrm{cm}^{-3}$, with an average of $700 \pm 260$ particles $\mathrm{cm}^{-3}$, during the polluted periods, which was approximately two to three times higher than the values obtained during the clean periods (range: 53-1100 particles $\mathrm{cm}^{-3}$; average: $280 \pm 160$ particles $\mathrm{cm}^{-3}$ ). Similarly, TSP concentrations during the polluted period 


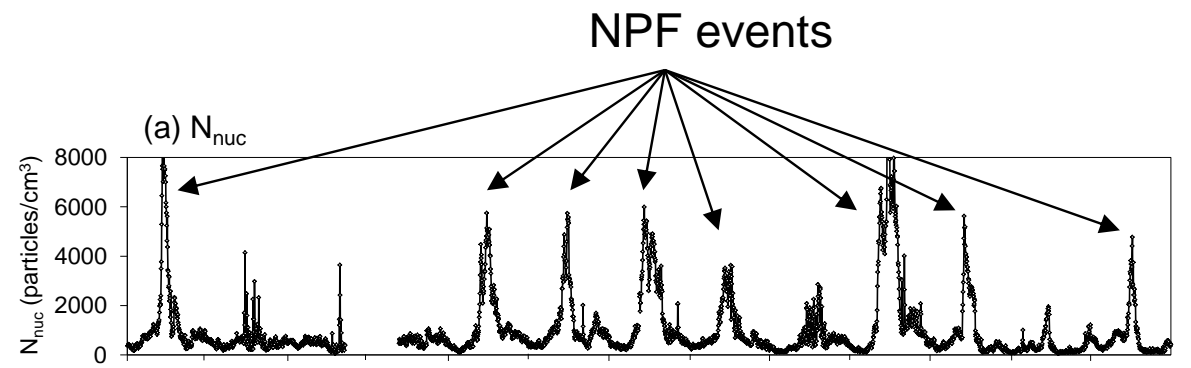

(b) $20 \mathrm{~nm}$

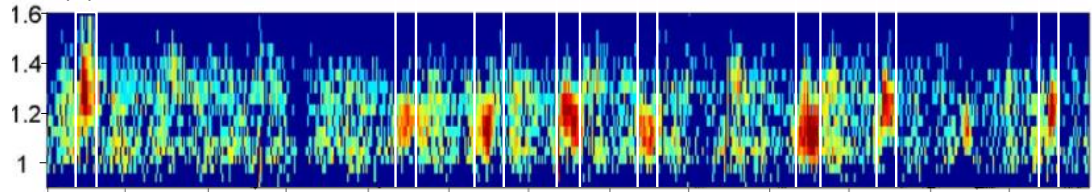

(c) $40 \mathrm{~nm}$

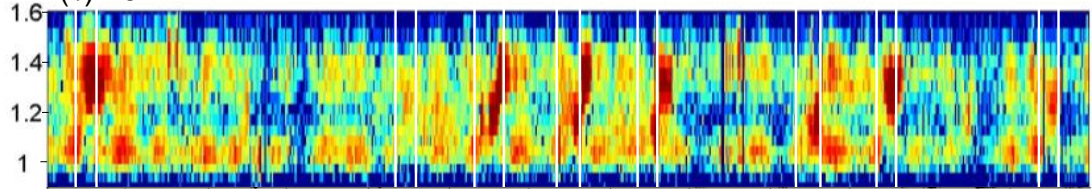

(d) $60 \mathrm{~nm}$

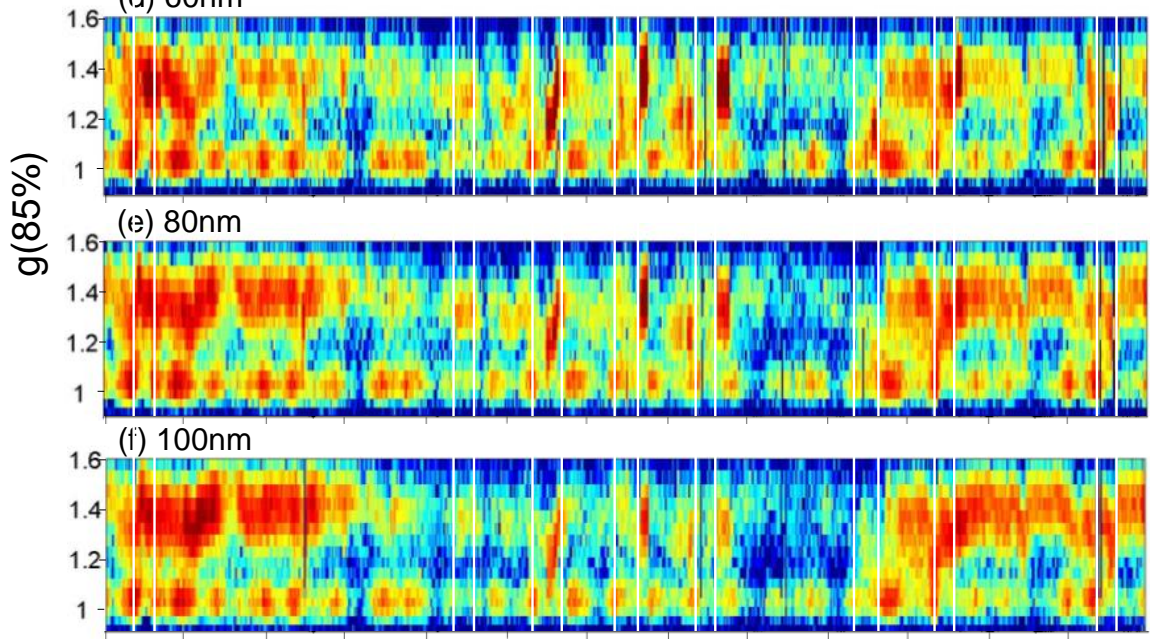

(g) $120 \mathrm{~nm}$

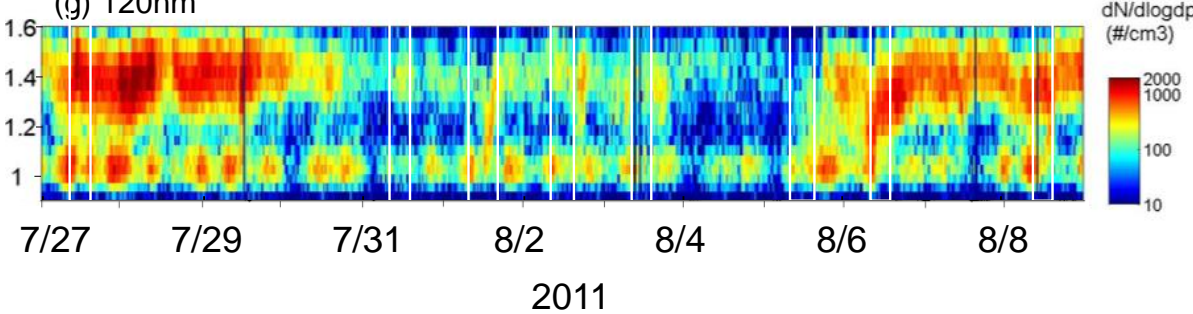

Figure 3. (a) $N_{\text {nuc }}$ and (b-g) temporal evolutions of the number concentrations of atmospheric particles as a function of the hygroscopic growth factor at $85 \% \mathrm{RH}[g(85 \%)]$ at the measurement site between 27 July and 8 August 2011. Dry particle diameter $\left(D_{\mathrm{p}}\right)$ increases from (b) $20 \mathrm{~nm}$ to (g) $120 \mathrm{~nm}$ with a $20 \mathrm{~nm}$ increment. Eight new particle formation (NPF) events were identified on 27 and 31 July, and 1-3, 5, 6, and 8 August 2011, as marked by white boxes.

ranged from 9 to $80 \mu \mathrm{g} \mathrm{m}^{-3}\left(33 \pm 16 \mu \mathrm{g} \mathrm{m}^{-3}\right)$, which were approximately two to three times higher than those (1$48 \mu \mathrm{g} \mathrm{m}^{-3}, 14 \pm 9 \mu \mathrm{g} \mathrm{m}^{-3}$ ) obtained during the clean period.

Figure $2 b$ and $c$ shows the air mass backward trajectories for the measurement site during the polluted and clean peri- ods, respectively. Local wind direction and wind speed during both periods are also shown in Fig. 2d and e, respectively. These backward trajectories indicate that during the polluted period air masses originated from the downwind areas of the Asian continent (Fig. 2b), whereas during the clean period 


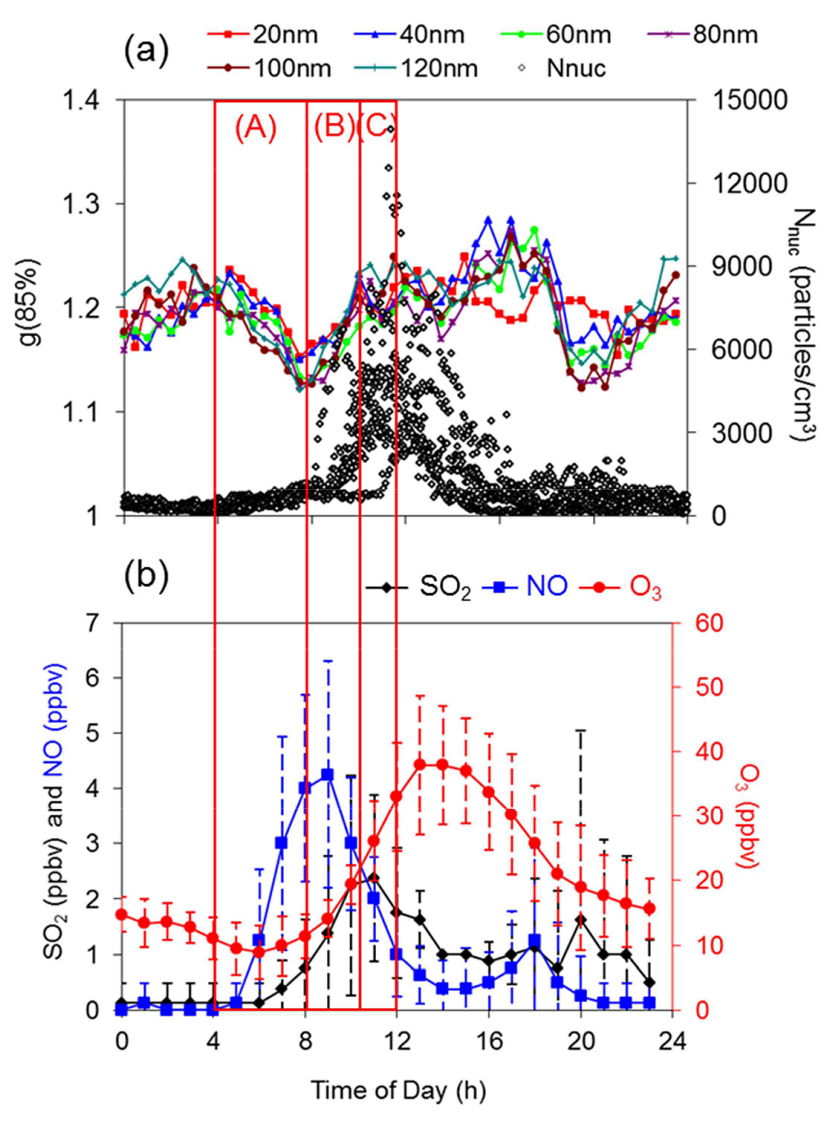

Figure 4. Diel variations in (a) median $g(85 \%)$ values in the dry $D_{\mathrm{p}}$ range of 20-120 nm with a $20 \mathrm{~nm}$ increment and $N_{\text {nuc }}$, and (b) $\mathrm{SO}_{2}$, $\mathrm{NO}$, and $\mathrm{O}_{3}$ concentrations during the NPF events. $g(85 \%)$ at dry $D_{\mathrm{p}}=20,40,60$, and $80 \mathrm{~nm}$ were converted to equivalent $g(85 \%)$ of dry $D_{\mathrm{p}}=100 \mathrm{~nm}$ by considering the Kelvin effect. Error bars in (b) represent standard deviations $(1 \sigma)$ of $\mathrm{SO}_{2}, \mathrm{NO}$, and $\mathrm{O}_{3}$ concentrations.

the air masses originated from the northwest Pacific (Fig. 2c). Local wind direction also clearly differed during the two periods, with a dominance of northwesterly winds during the polluted period but southeasterly winds during the clean period. These results suggest that variations in $N_{80-165 \mathrm{~nm}}$ are largely affected by the inflow of different air masses.

Figure 3 shows $N_{\text {nuc }}$ and the number distributions of humidified particles at the dry $D_{\mathrm{p}}$ range of $20-120 \mathrm{~nm}$ as a function of $g(85 \%)$. During the measurement period, eight NPF events occurred on 27, 31 July, and 1-3, 5, 6, and 8 August, as shown in Fig. 3a and marked as white boxes. An NPF event was defined as a sharp increase in the $N_{\text {nuc }} /$ number concentration of ultrafine particles $\left(N_{\text {UFP }}: 7-100 \mathrm{~nm}\right)$ ratios of $>0.5$ with elevated $N_{\text {UFP }}$ (refer to Fig. 3 in Jung et al., 2013). Increases in the number concentrations of humidified particles at a dry $D_{\mathrm{p}}$ of $20 \mathrm{~nm}$ were observed during the NPF event periods (Fig. 3b). Increases in the number concentrations of humidified particles at a dry $D_{\mathrm{p}}$ of $40 \mathrm{~nm}$ were observed after the burst of humidified particles at a dry $D_{\mathrm{p}}$ of
$20 \mathrm{~nm}$ occurred. Variations in the hygroscopicity of freshly formed nucleation mode particles and nucleated particles that had grown to Aitken mode sizes are discussed in Sect. 3.4.

Elevated number concentrations of humidified particles at the dry $D_{\mathrm{p}}$ range of $80-120 \mathrm{~nm}$ were observed during the periods 27-29 July and 6-8 August, whereas low number concentrations of particles were observed between 30 July and 5 August. Variations in the number distributions of humidified particles and $g(85 \%)$ values at dry $D_{\mathrm{p}}=80 \mathrm{~nm}$ were fairly similar to those at dry $D_{\mathrm{p}}=120 \mathrm{~nm}$. Elevated number concentrations of smaller particles (dry $D_{\mathrm{p}}=20$ and $40 \mathrm{~nm}$ ) were observed between 30 July and 5 August due to NPF events as shown in Fig. 3a. Increases in the number concentrations of larger particles (dry $D_{\mathrm{p}}>80 \mathrm{~nm}$ ) were also observed during the same period, but with some time delay. This can be explained by either the condensational growth of newly formed particles or the inflow of different air masses due to the change in local wind direction. The hygroscopic properties of the nucleation and Aitken mode particles during the NPF episodes are discussed in Sect. 3.5.

\subsection{Diel variations in hygroscopic growth factors of size-segregated ultrafine particles}

The $g(85 \%)$ of particles at a dry $D_{\mathrm{p}}$ of $<100 \mathrm{~nm}$ is less than that of equivalent larger particles $\left(D_{\mathrm{p}}>100 \mathrm{~nm}\right)$ due to the Kelvin effect. As most previous studies measured growth factors of nebulized particles at a dry $D_{\mathrm{p}}$ of $100 \mathrm{~nm}$ (e.g., Gysel et al., 2004; Sjogren et al., 2008; Jung et al., 2011), the $g(85 \%)$ of particles at a dry $D_{\mathrm{p}}$ of $<100 \mathrm{~nm}$ were converted to those of equivalent larger particles assuming a dry $D_{\mathrm{p}}$ of $100 \mathrm{~nm}$. Hereafter, the converted terms are denoted as Equiv. $g(85 \%)$ at dry $D_{\mathrm{p}}=100 \mathrm{~nm}$. As the $g(85 \%)$ of a dry $D_{\mathrm{p}}<100 \mathrm{~nm}$ before correction was similar to that of water-soluble organic aerosols, but much lower than that of inorganic compounds such as ammonium sulfate (Table 1), this study used the $g(\mathrm{RH})$ curve of water-soluble organic aerosols obtained by Jung et al. (2011). Thus, the conversion was based on the Köhler equation using the $g(\mathrm{RH})$ curve of water-soluble organic aerosols. The surface tension of pure water was used to correct for the Kelvin effect on ultrafine particles. The surface tension of water mixed with $\left(\mathrm{NH}_{4}\right)_{2} \mathrm{SO}_{4}$ increases to approximately $12 \%$ higher than that of pure water (Lee and Hildemann, 2013), whereas that of water mixed with organic aerosols such as HULIS (humiclike substance) decreases by about $30 \%$ when compared with that of pure water (Salma et al., 2006). Using these two extreme cases to correct for the Kelvin effect on the $g(\mathrm{RH})$ of ultrafine particles, the average Equiv. $g(85 \%)$ of dry $D_{\mathrm{p}}=20 \mathrm{~nm}$ (Table 1 ) was calculated to be 1.21 to 1.24 , whereas that of dry $D_{\mathrm{p}}=40 \mathrm{~nm}$ was 1.28 to 1.3 , which is comparable with that of dry $D_{\mathrm{p}}=20 \mathrm{~nm}(1.23)$ and $40 \mathrm{~nm}$ (1.3) calculated using the surface tension of pure water. As the uncertainty associated with the different values of surface 
Table 1. Mode $D_{\mathrm{p}}$ and $g(85 \%)$ values of freshly formed nucleation mode particles and nucleated particles that grew to Aitken mode size at the Sapporo study site.

\begin{tabular}{lcccccc}
\hline Date & \multicolumn{3}{c}{$\begin{array}{c}\text { Freshly formed nucleation } \\
\text { mode particles }\end{array}$} & \multicolumn{3}{c}{$\begin{array}{c}\text { Nucleated particles that grew } \\
\text { to Aitken mode size }\end{array}$} \\
\cline { 2 - 7 } & $\begin{array}{c}\text { Mode } \\
D_{\mathrm{p}}(\mathrm{nm})\end{array}$ & $\begin{array}{c}g(85 \%) \text { at dry } \\
\left.D_{\mathrm{p}}=20 \mathrm{~nm}^{1}\right)\end{array}$ & $\begin{array}{c}\text { Equiv. } g(85 \%) \text { at dry } \\
\left.D_{\mathrm{p}}=100 \mathrm{~nm}^{2}\right)\end{array}$ & $\begin{array}{c}\text { Mode } D_{\mathrm{p}} \\
(\mathrm{nm})\end{array}$ & $\begin{array}{c}g(85 \%) \text { at dry } \\
D_{\mathrm{p}}=40 \mathrm{~nm}^{3)}\end{array}$ & $\begin{array}{c}\text { Equiv. } g(85 \%) \text { at dry } \\
\left.D_{\mathrm{p}}=100 \mathrm{~nm}^{2}\right)\end{array}$ \\
\hline 27-Jul-11 & 24 & 1.28 & 1.35 & 44 & 1.31 & 1.34 \\
31-Jul-11 & 12 & 1.12 & 1.19 & & & \\
01-Aug-11 & 14 & 1.11 & 1.17 & 48 & 1.26 & 1.29 \\
02-Aug-11 & 15 & 1.17 & 1.24 & & & \\
03-Aug-11 & 14 & 1.12 & 1.19 & & & \\
05-Aug-11 & 13 & 1.11 & 1.17 & & & 1.31 \\
06-Aug-11 & 22 & 1.22 & 1.29 & 47 & 1.28 & 1.24 \\
08-Aug-11 & 18 & 1.16 & 1.23 & 38 & 1.21 & 1.34 \\
Min & 12 & 1.11 & 1.17 & 38 & 1.21 & 1.30 \\
Max & 24 & 1.28 & 1.35 & 48 & 1.31 & 0.04 \\
Average & 16 & 1.16 & 1.23 & 44 & 1.27 & \\
SD & 4.0 & 0.06 & 0.06 & 4.5 & 0.04 & \\
\hline
\end{tabular}

${ }^{1} g(85 \%)$ at dry $D_{\mathrm{p}}=20 \mathrm{~nm}$ represent the $g(85 \%)$ of freshly formed nucleation mode particles.

$2 g(85 \%)$ at dry $D_{\mathrm{p}}=20$ and $40 \mathrm{~nm}$ were converted to Equiv. $g(85 \%)$ of dry $D_{\mathrm{p}}=100 \mathrm{~nm}$ by considering the Kelvin effect.

${ }^{3} g(85 \%)$ at dry $D_{\mathrm{p}}=40 \mathrm{~nm}$ represent the $g(85 \%)$ of the Aitken mode particles.

(a) $\bigcirc$ dry $D p=20 \mathrm{~nm} \quad \square$ dry $D p=40 \mathrm{~nm}$

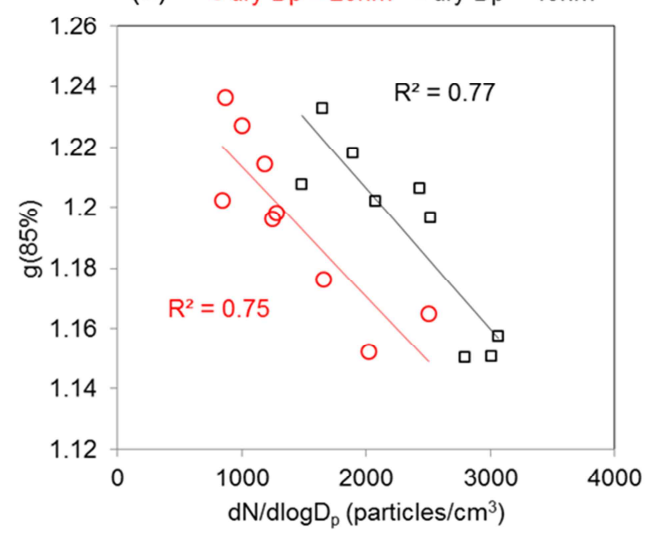

(b) $\quad$ dry $D p=60 \mathrm{~nm} \square$ dry $D p=80 \mathrm{~nm}$

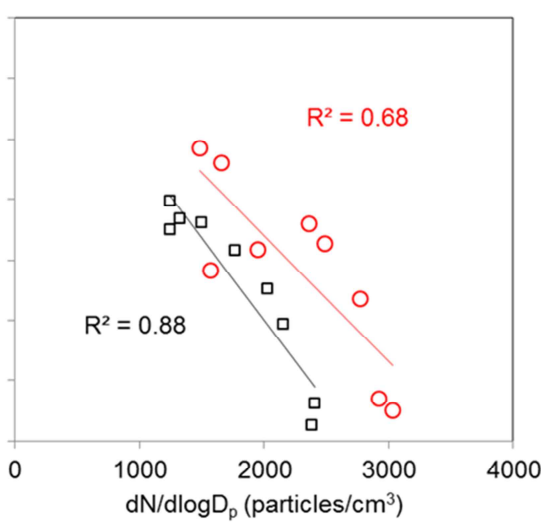

(c) $O$ dry $\mathrm{Dp}=100 \mathrm{~nm} \square$ dry $\mathrm{Dp}=120 \mathrm{~nm}$

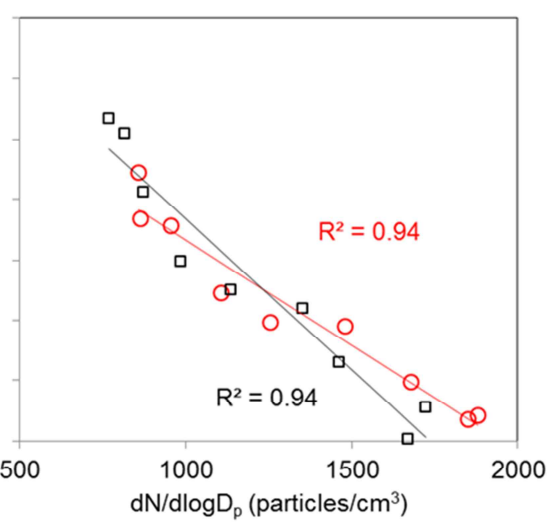

Figure 5. Scatter plots of $g(85 \%)$ versus particle number concentrations in each size bin during the NPF events. (a) Dry $D_{\mathrm{p}}=20$ and $40 \mathrm{~nm}$. (b) Dry $D_{\mathrm{p}}=60$ and $80 \mathrm{~nm}$. (c) Dry $D_{\mathrm{p}}=100$ and $120 \mathrm{~nm}$. The data points are 30 min averaged $g(85 \%)$ values and particle number concentrations from 04:00 to 08:00 LT are marked (A) in Fig. 4a and c.

tension is negligible, the surface tension of pure water was used in this study.

Figure $4 \mathrm{a}$ shows the diel variations in median $g(85 \%)$ at the dry $D_{\mathrm{p}}$ range of $20-120 \mathrm{~nm}$ and $N_{\text {nuc }}$ during the NPF event periods. Values of $g(85 \%)$ at dry $D_{\mathrm{p}}=20,40,60$, and $80 \mathrm{~nm}$ in Fig. $4 \mathrm{a}$ are Equiv. $g(85 \%)$ at dry $D_{\mathrm{p}}=100 \mathrm{~nm}$. The burst of nucleation mode particles and $g(85 \%)$ at the dry $D_{\mathrm{p}}$ range of 20-120 nm were characterized by three phases marked as A, B, and C in Fig. 4. A gradual increase in $N_{\text {nuc }}$ and significant decrease in $g(85 \%)$ were observed between 5:00 and 8:00 LT (Phase A) when NO concentrations significantly increased from near 0 to around 4 ppbv (Fig. 4b).
In Phase B, both $N_{\text {nuc }}$ and $g(85 \%)$ values increased significantly between 08:00 and 10:30 LT, together with increases in $\mathrm{SO}_{2}$ and $\mathrm{O}_{3}$ concentrations. In Phase C, peak $N_{\text {nuc }}$ and relatively constant $g(85 \%)$ values were observed during the period 10:30-12:00 LT, together with a continuous increase in $\mathrm{O}_{3}$ concentrations.

The median $g(85 \%)$ values at the dry $D_{\mathrm{p}}$ range of 20-120 nm gradually decreased during the period 04:0008:00 LT as NO concentration increased (Fig. 4). The decrease in $g(85 \%)$ values, accompanied by an increase in NO concentrations in the morning, suggests that the decrease in $g(85 \%)$ values during Phase A can be attributed 


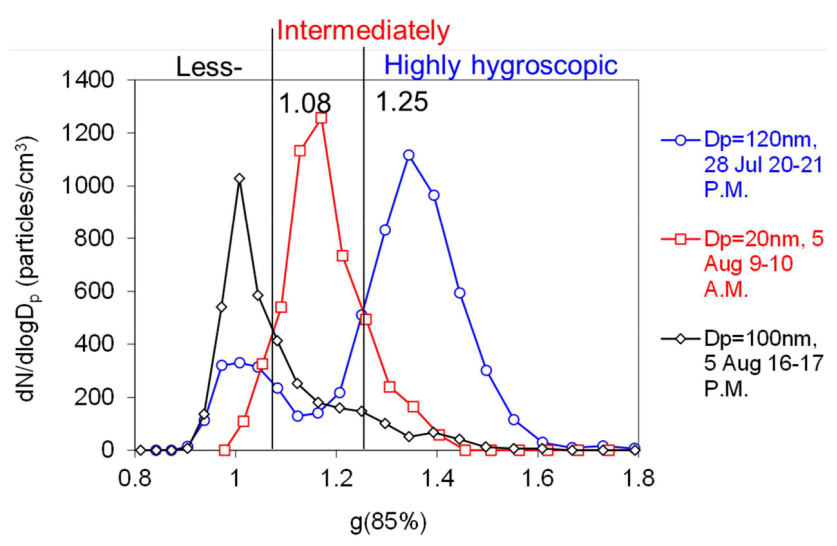

Figure 6. Lognormal number distributions of humidified particles as a function of $g(85 \%)$ values on 5 August (16:00-17:00 LT) at dry $D_{\mathrm{p}}=100 \mathrm{~nm}, 5$ August (09:00-10:00 LT) at dry $D_{\mathrm{p}}=20 \mathrm{~nm}$, and 28 July (20:00-21:00 LT) at dry $D_{\mathrm{p}}=120 \mathrm{~nm}$ as typical examples for less-, intermediately, and highly hygroscopic particles, respectively. Vertical lines at $g(85 \%)$ values of 1.08 and 1.25 represent threshold values between less-, intermediately, and highly hygroscopic fractions. $g(85 \%)$ at dry $D_{\mathrm{p}}=20 \mathrm{~nm}$ is Equiv. $g(85 \%)$ at dry $D_{\mathrm{p}}=100 \mathrm{~nm}$.

to increased emissions of water-insoluble ultrafine particles, probably from traffic. As seen in Fig. 5, $g(85 \%)$ decreases with an increase in the number concentration of particles in each size bin between 4:00 and 8:00 LT. Thus, waterinsoluble particles from traffic are important to the hygroscopic properties of particles within the dry $D_{\mathrm{p}}$ range of 40 $120 \mathrm{~nm}$ prior to the burst of nucleation mode particles.

The $g(85 \%)$ values at dry $D_{\mathrm{p}}=20 \mathrm{~nm}$ increased as $N_{\text {nuc }}$ increased during Phase $\mathrm{B}$, when the burst of nucleation mode particles occurred (Fig. 4a), suggesting that freshly formed nucleation mode particles are enriched with water-soluble components. Simultaneous increases in the $g(85 \%)$ values in the dry $D_{\mathrm{p}}$ range of $40-120 \mathrm{~nm}$ were observed during Phase $\mathrm{B}$ together with increased concentrations of $\mathrm{O}_{3}$ and $\mathrm{SO}_{2}$. The increased $g(85 \%)$ values can be explained by the subsequent growth of freshly formed nucleation mode particles to the Aitken mode or by the condensation of watersoluble inorganic species or organic vapors onto pre-existing Aitken mode particles. Almost constant $g(85 \%)$ values were obtained within the dry $D_{\mathrm{p}}$ range of $20-120 \mathrm{~nm}$ when $N_{\text {nuc }}$ maximized during Phase C (Fig. 4a).

\subsection{Categorization of hygroscopic properties of ultrafine particles}

As shown in Fig. 6, particle number concentrations generally exhibited unimodal or bimodal distributions as a function of $g(85 \%)$. Freshly formed nucleation mode particles typically showed a unimodal distribution (Fig. 3b). Based on the number distributions of humidified particles as a function of $g(85 \%)$, particle distributions were divided into three categories: the less-, intermediately, and highly hygroscopic fractions. Particle number distributions are shown as a function of $g(85 \%)$ for 5 August, 16:00-17:00 LT, at dry $D_{\mathrm{p}}=100 \mathrm{~nm} ; 5$ August, 09:00-10:00 LT, at dry $D_{\mathrm{p}}=20 \mathrm{~nm}$; and 28 July, 20:00-21:00 LT, at dry $D_{\mathrm{p}}=120 \mathrm{~nm}$, as typical examples of the less-, intermediately and highly hygroscopic particles, respectively (Fig. 6). $g(85 \%)$ at dry $D_{\mathrm{p}}=20 \mathrm{~nm}$ in Fig. 6 is Equiv. $g(85 \%)$ at dry $D_{\mathrm{p}}=100 \mathrm{~nm}$. The lesshygroscopic mode was frequently observed when elevated highly hygroscopic mode distributions were observed as seen in Figs. 3 and 6. This bimodal distribution can be explained by the mixing of locally emitted insoluble particles and a complex mixture of long-range transported water-soluble and water-insoluble particles within the Asian continental outflows (Seinfeld et al., 2004). Highly hygroscopic particles within the Asian outflows are discussed in Sect. 3.6. A $g(85 \%)$ threshold of 1.08 was used to separate the less- from the intermediately hygroscopic fractions, while a threshold of 1.25 was selected to distinguish between the intermediately and highly hygroscopic fractions. The number fractions of the three hygroscopic categories were calculated using these two threshold values. Mochida et al. (2008) used similar threshold values of 1.11 and 1.29 for the separation of the three hygroscopic fractions.

The $g(85 \%)$ values of water-soluble inorganic ions are generally higher than 1.5 (Jung et al., 2011). It is well known that elemental carbon, crustal elements, and water-insoluble organics have $g(85 \%)$ values of approximately 1 . As the size of crustal elements is generally larger than $100 \mathrm{~nm}$, the less-hygroscopic ultrafine particles in the urban atmosphere can be attributed to elemental carbon and water-insoluble organic aerosols (Kuwata et al., 2007). $g(85 \%)$ values of water-soluble organics have been measured previously and fall within a range from around 1.1 to 2.2 (Virkkula et al., 1999; Saathoff et al., 2003; Sjogren et al., 2008; Jung et al., 2011). Thus, intermediately hygroscopic particles can be attributed to water-soluble SOA, including a small fraction of water-soluble primary organic aerosols. As elevated levels of intermediately hygroscopic particles were typically observed during the NPF events, freshly formed nucleation mode particles may contain abundant water-soluble SOA. Peak number concentrations of highly hygroscopic particles were obtained at a $g(85 \%)$ of about 1.4. As this value is lower than that of water-soluble inorganic species such as ammonium sulfate, highly hygroscopic particles can be attributed to a mixture of secondary organic aerosols and inorganic ions.

\subsection{Hygroscopic growth factors of freshly formed nucleation mode particles during the NPF events}

A mode peak diameter (Mode $D_{\mathrm{p}}$ ) was obtained from a lognormal Gaussian fit of particle number size distribution smaller than $100 \mathrm{~nm}$. The Mode $D_{\mathrm{p}}$ of freshly formed nucleation mode particles was obtained from particle number size distributions averaged over the $1 \mathrm{~h}$ period from the 


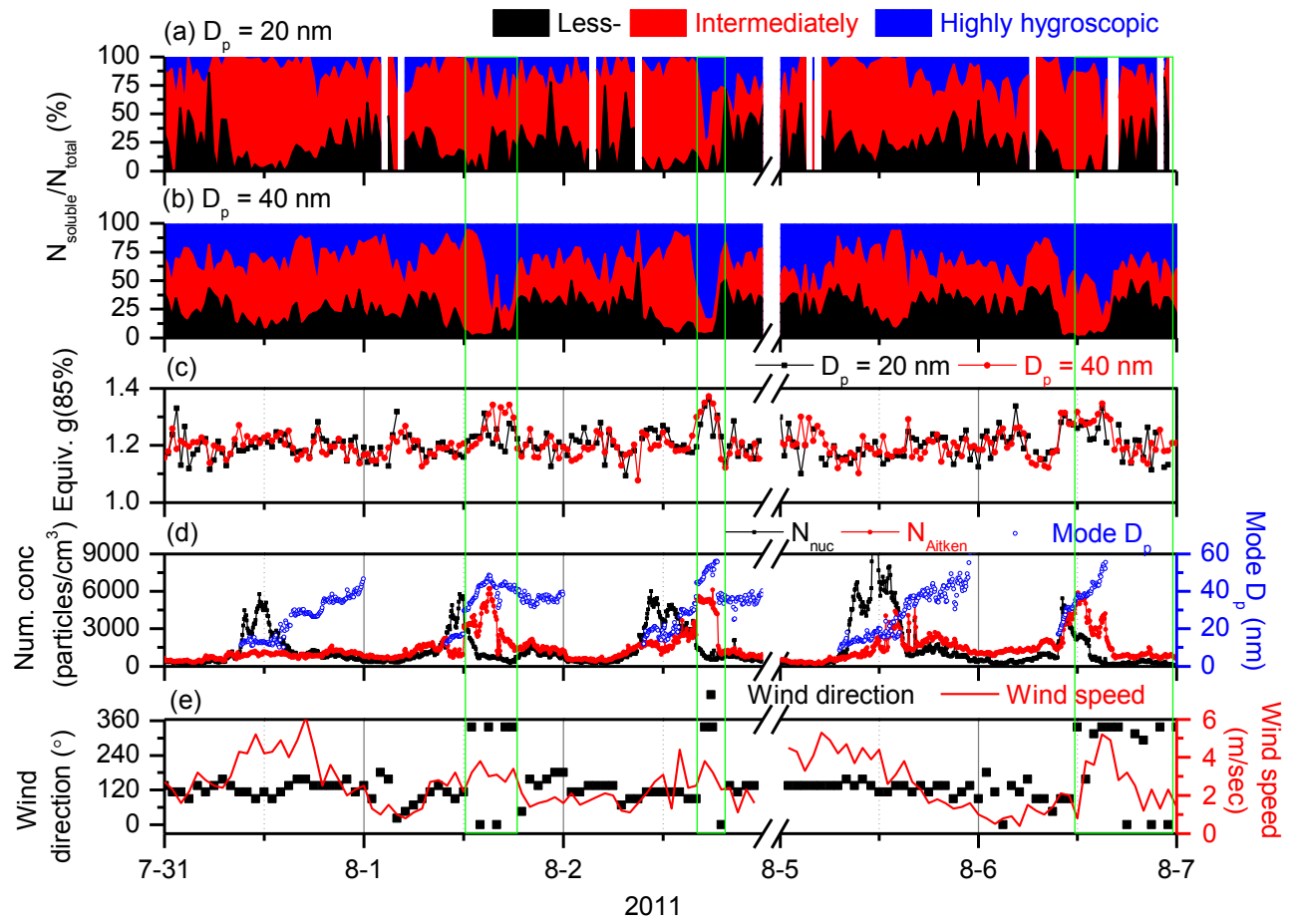

Figure 7. Temporal variations in number fractions of less-, intermediately, and highly hygroscopic particles at dry $D_{\mathrm{p}}$ values of (a) $20 \mathrm{~nm}$ and (b) $40 \mathrm{~nm}$. (c) $g(85 \%)$ values of total particles at dry $D_{\mathrm{p}}$ values of 20 and $40 \mathrm{~nm}$. (d) $N_{\text {nuc }}$, Aitken (30-100 nm) mode particles $\left(N_{\text {Aitken }}\right)$, and Mode $D_{\mathrm{p}}$ during the periods 31 July-2 August and 5-6 August. (e) Temporal variations in wind direction and wind speed are also shown. Rectangles represent northwesterly or northeasterly wind directions.

beginning of the burst of nucleation mode particles. Similarly, the Mode $D_{\mathrm{p}}$ of nucleated particles that had grown to Aitken mode sizes, hereafter referred to as the Aitken mode particles, was obtained from particle number size distribution averaged over the $1 \mathrm{~h}$ period before the end of a linear growth of the Mode $D_{\mathrm{p}}$ of freshly formed nucleation mode particles (Jung et al., 2013). The Mode $D_{\mathrm{p}}$ of freshly formed nucleation mode particles ranged from 12 to $24 \mathrm{~nm}$, with an average of $16 \pm 3 \mathrm{~nm}$, whereas the Mode $D_{\mathrm{p}}$ of particles after particle growth ranged from 38 to $48 \mathrm{~nm}$, with an average of $44 \pm 5 \mathrm{~nm}$ (Table 1). As the average Mode $D_{\mathrm{p}}$ values of the freshly formed nucleation mode particles and the Aitken mode particles were close to 20 and $40 \mathrm{~nm}$, respectively, the $g(85 \%)$ values at a dry $D_{\mathrm{p}}$ of 20 and $40 \mathrm{~nm}$ were used to investigate the hygroscopic properties of freshly formed nucleation mode particles and the Aitken mode particles, respectively.

As only unimodal size distributions were observed for freshly formed nucleation mode particles (Fig. 3b) and the Aitken mode particles (Fig. 3c), the $g(85 \%)$ values for these two types of particles were obtained from a Gaussian fit of the number size distributions of humidified particles at dry a $D_{\mathrm{p}}$ of 20 and $40 \mathrm{~nm}$, respectively, during nucleation burst events. Therefore, $g(85 \%)$ values of freshly formed nucleation mode particles and the Aitken mode particles were denoted as $g(85 \%)$ _fresh and $g(85 \%) \_$Aitken, respectively. Dur- ing the NPF periods, $g(85 \%)$ fresh ranged from 1.11 to 1.28 , with an average of $1.16 \pm 0.06$, which is equivalent to the range of 1.17 to 1.35 with an average of $1.23 \pm 0.06$ at dry $D_{\mathrm{p}}=100 \mathrm{~nm}$, whereas $g(85 \%)$ Aitken ranged from 1.21 to 1.31 , with an average of $1.27 \pm 0.04$, which is equivalent to the range of 1.24 to 1.34 , with an average of $1.30 \pm 0.04$, at dry $D_{\mathrm{p}}=100 \mathrm{~nm}$ (Table 1$)$.

The $g(85 \%)$ value of $\left(\mathrm{NH}_{4}\right)_{2} \mathrm{SO}_{4}$ measured here using the H-TDMA was $1.56 \pm 0.01$. Laboratory photo-oxidation experiments show that $g(85 \%)$ values of the SOA derived from volatile organic compounds fall within the range 1.011.16 (Virkkula et al., 1999; Saahoff et al., 2003; Varutbangkul et al., 2006), whereas those of the ambient SOA are around 1.20 (Sjogren et al., 2008; Jung et al., 2011). Average $g(85 \%)_{\text {_fresh }}$ at the urban site in the present study were much lower than the $g(85 \%)$ of $\left(\mathrm{NH}_{4}\right)_{2} \mathrm{SO}_{4}$, whereas they were comparable with those of previously studied secondary SOA (Sjogren et al., 2008; Jung et al., 2011). Thus, this result indicates that organic vapors were the main contributors to the burst of nucleation mode particles in the Sapporo atmosphere during the summer of 2011.

Average values of Equiv. $g(85 \%)_{\text {Aitken }}$ at dry $D_{\mathrm{p}}=100 \mathrm{~nm}$ of the Aitken mode particles were slightly higher than those of newly formed nucleation mode particles (Table 1), suggesting that the growth of freshly formed nucleation mode particles to the Aitken mode size can be 
subjected to condensation of not only low-volatility organic vapors but also water-soluble inorganic species. Pavuluri et al. (2013) measured radiocarbon in the WSOC fraction of the aerosols collected at the same site. They found that, during the summer of 2010 , about $88 \%$ of the WSOC consisted of modern carbon. This indicates that a large fraction of this WSOC had originated from biogenic emissions from urban Sapporo and the surrounding mixed deciduous forests. Thus, it is suggested that NPF and the subsequent growth of the particles at the measurement site are highly affected by biogenic organic emissions.

Ehn et al. (2007) reported the opposite trend in the hygroscopic properties of freshly formed nucleation mode particles in a boreal coniferous forest in southern Finland; that is, they found that the hygroscopic growth factors of freshly formed nucleation mode particles decreased as particles grew to the Aitken mode. The contrast in the behavior of the hygroscopic properties reported here and by Ehn et al. (2007) indicates that differences may exist in the formation mechanisms of the freshly nucleated particles, or in their growth mechanisms, between the boreal coniferous forest in southern Finland and the Sapporo urban site adjacent to a deciduous forest in northern Japan.

\subsection{Temporal variations in hygroscopic growth factors of the newly formed particles during the NPF and their subsequent growth periods}

Figure 7 shows the temporal variations in the number fractions of the less-, intermediately, and highly hygroscopic particles and Equiv. $g(85 \%)$ values of a dry $D_{\mathrm{p}}$ of 20 and $40 \mathrm{~nm}$ between 31 July and 2 August, and 5 and 6 August. Increased number fractions of intermediately hygroscopic particles at dry $D_{\mathrm{p}}=20 \mathrm{~nm}$ were observed when the burst of nucleation mode particles occurred (Fig. 7a, d), indicating that the hygroscopic property of freshly formed nucleation mode particles is intermediate. High fractions of intermediately hygroscopic particles were also obtained at dry $D_{\mathrm{p}}=40 \mathrm{~nm}$, when the burst of nucleation mode particles and the subsequent gradual growth occurred on 31 July and 2 and 5 August under southerly wind conditions. This result indicates that the subsequent growth of freshly formed nucleation mode particles can be attributed mainly to intermediately hygroscopic vapors.

Temporal variations in the Equiv. $g(85 \%)$ at dry $D_{\mathrm{p}}=20$ and $40 \mathrm{~nm}$, and Mode $D_{\mathrm{p}}$ demonstrate that the subsequent growth of freshly formed nucleation mode particles and their hygroscopic properties were highly affected by the local wind direction (Fig. 7). Under southerly wind conditions on 31 July and 5 August, gradual increases in Mode $D_{\mathrm{p}}$ occurred with a dominant contribution from intermediately hygroscopic particles. However, sharp increases in Mode $D_{\mathrm{p}}$ occurred when the wind direction shifted to northwesterly or northeasterly on 1, 2, and 6 August, with a sharp increase in highly hygroscopic particle fraction at dry $D_{\mathrm{p}}=40 \mathrm{~nm}$.

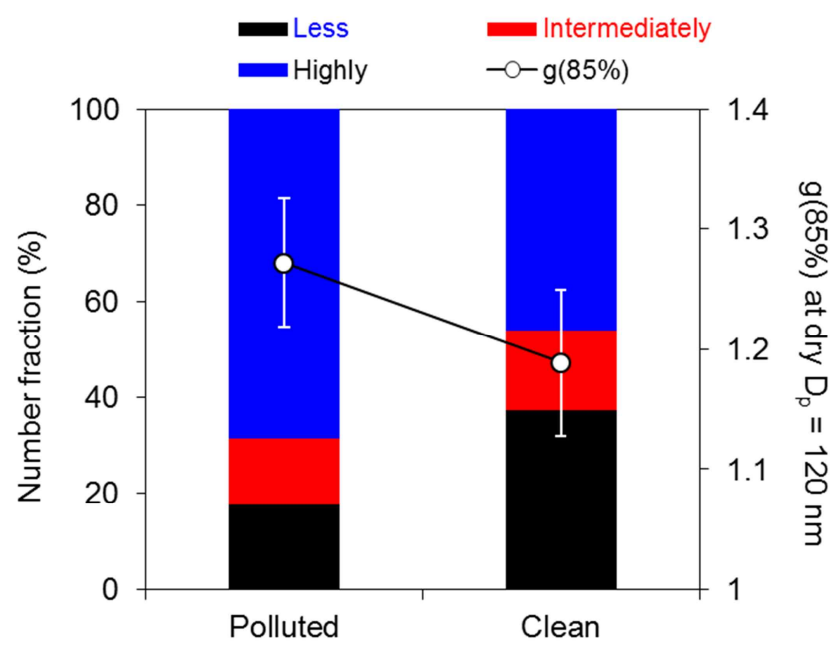

Figure 8. Average number fractions of less-, intermediately, and highly hygroscopic particles at dry $D_{\mathrm{p}}$ values of $120 \mathrm{~nm}$ during the polluted and clean periods. Average $g(85 \%)$ values of particles are also shown. Error bar represents $1 \sigma$ of $g(85 \%)$ value.

Sudden changes in Mode $D_{\mathrm{p}}$ and hygroscopic growth factor imply that completely different air masses arrived at the measurement site under northwesterly or northeasterly wind conditions. Thus, the hygroscopic growth factor of newly formed particles was perturbed by the local winds that delivered different air masses to the measurement site.

\subsection{Hygroscopic properties of large Aitken and accumulation mode particles}

Figure 8 shows the average number fractions of the less-, intermediately, and highly hygroscopic particles to total particles at dry $D_{\mathrm{p}}=120 \mathrm{~nm}$ as a typical example of the large Aitken to small accumulation mode particles. The number fractions of the less-, intermediately, and highly hygroscopic particles at dry $D_{\mathrm{p}}=120 \mathrm{~nm}$ were found to be $18 \pm 9 \%$, $14 \pm 8 \%$, and $69 \pm 14 \%$, respectively, during the polluted period. However, different number fractions of the three hygroscopic particles were obtained during the clean period of $37 \pm 14 \%, 17 \pm 8 \%$, and $46 \pm 16 \%$, respectively (Fig. 8). Significantly higher $g(85 \%)$ values at dry $D_{\mathrm{p}}=120 \mathrm{~nm}$ were obtained during the polluted periods $(1.27 \pm 0.05)$ than the clean period $(1.19 \pm 0.06)$. The elevated number fractions of highly hygroscopic particles and higher $g(85 \%)$ values at dry $D_{\mathrm{p}}=120 \mathrm{~nm}$ during the polluted period compared with the clean period imply that air masses originating from downwind areas of the Asian continent contain high amounts of highly hygroscopic Aitken to accumulation mode particles. To better understand the hygroscopic properties of Aitken and accumulation mode particles, size-segregated chemical measurements will be required in a future study.

The number concentrations of less-hygroscopic particles in the dry $D_{\mathrm{p}}$ range of $20-120 \mathrm{~nm}$ increased during the early 


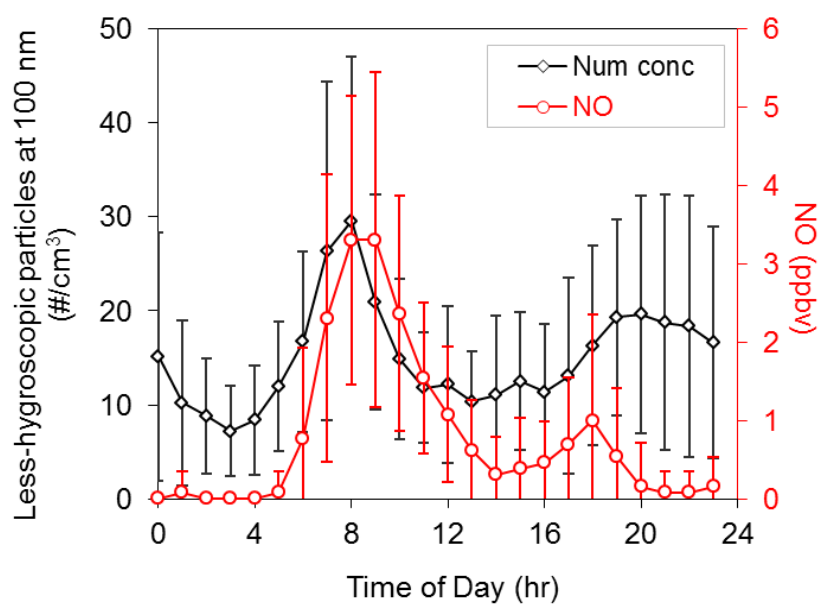

Figure 9. Diel variations in less-hygroscopic particles at dry $D_{\mathrm{p}}=100 \mathrm{~nm}$, and NO concentrations during the entire measurement periods. Error bars represent $1 \sigma$ of number concentration of lesssoluble particles at dry $D_{\mathrm{p}}=100 \mathrm{~nm}$ and NO concentration.

morning and evening, with the exception of dry $D_{\mathrm{p}}=20 \mathrm{~nm}$ (Fig. 3). Figure 9 shows diel variations in the number concentration of less-hygroscopic particles at dry $D_{\mathrm{p}}=100 \mathrm{~nm}$ and also in the NO concentration. Diel variations in the number concentration of less-hygroscopic particles showed two peaks at 07:00-08:00 LT and 19:00-20:00 LT. The NO concentrations showed a similar diel variation, with a major peak at 08:00-09:00 LT and a minor peak at 18:00 LT. These results imply that less-hygroscopic particles might be directly emitted from local anthropogenic sources such as traffic and cooking activities.

\section{Summary and conclusions}

The burst of nucleation mode particles and median $g(85 \%)$ values in the dry $D_{\mathrm{p}}$ range of $20-120 \mathrm{~nm}$ were characterized by three phases: small increases in $N_{\text {nuc }}$ and sharp decreases in $g(85 \%)$ between 05:00 and 08:00 LT; sharp increases in $N_{\text {nuc }}$ and $g(85 \%)$ between 08:00 and 10:30 LT; and peak $N_{\text {nuc }}$ and relatively constant $g(85 \%)$ between 10:30 and 12:00 LT. Small increases in $N_{\text {nuc }}$ and sharp decreases in $g(85 \%)$, together with large increases in NO concentrations, during the period 05:00-08:00 LT suggest that waterinsoluble particles emitted from traffic play an important role in lowering the hygroscopicity of ultrafine particles prior to the burst of nucleation mode particles. Sharp increases in both $N_{\text {nuc }}$ and $g(85 \%)$, accompanied by simultaneous increases in $\mathrm{SO}_{2}$ and $\mathrm{O}_{3}$ concentrations, during the period 08:00-10:30 LT may indicate that freshly formed nucleation mode particles are abundant with water-soluble components. The equivalent $g(85 \%)$ values of freshly formed nucleation mode particles at the urban site were 1.17-1.35 (average: $1.23 \pm 0.06)$. These hygroscopic growth factors are similar to those of secondary organic aerosols, suggesting that lowvolatility organic vapors are important to the burst of nucleation mode particles.

Diel variations in the less-hygroscopic particles at our urban study site in Sapporo, Japan, during the summer of 2011 were strongly correlated with NO concentrations, suggesting that less-hygroscopic particles are mainly produced from anthropogenic sources such as traffic. The $g(85 \%)$ values of total particles at dry $D_{\mathrm{p}}=120 \mathrm{~nm}$ were $1.27 \pm 0.05$ when air masses originating from downwind areas of the Asian continent arrived over the site and were higher than those $(1.19 \pm 0.06)$ brought by the marine air masses. These results indicate that the hygroscopic properties of large Aitken and small accumulation mode particles $(80-165 \mathrm{~nm})$ at our urban study site are highly influenced by the long-range transport of atmospheric particles from the Asian continent.

Organic vapors that are present in the urban atmosphere are generally emitted by in situ anthropogenic and biogenic sources, but they can also be transported into urban areas from surrounding forests. To better understand the effects of biogenic organic emissions on NPF and the subsequent growth mechanism in urban Sapporo, it will be necessary to quantify the proportions of particulate organic aerosols derived from anthropogenic and biogenic sources. These proportions can be determined by measuring radiocarbon and biogenic SOA tracers in sub- $\mu \mathrm{m}$ particles (Pavuluri et al., 2013). Further investigations of diel variations in biogenic SOA tracers and the radiocarbon isotopic ratios of nucleated particles will be necessary if we are to develop a better understanding of the interaction between biogenic and anthropogenic emissions and their effects on NPF, and the subsequent growth of freshly nucleated particles.

Acknowledgements. This work was in part supported by Grant-inAid Nos. 2100923509 and 24221001 from the Japan Society for the Promotion of Science (JSPS) and by the Environment Research and Technology Development Fund (B-0903) of the Ministry of the Environment, Japan. It was also supported by the Korea Research Council of Fundamental Science and Technology (KRCF) under the National Agenda Project of Development of Measurement Technology for Solving Climate Change (NAP-08-2). We appreciate the financial support provided by a JSPS Fellowship awarded to J. S. Jung. We acknowledge the Ministry of the Environment of Japan and the Japan Meteorological Agency for providing their pollutant data and meteorological parameters, respectively.

Edited by: V.-M. Kerminen 


\section{References}

Agarwal, S., Aggarwal, S. G., Okuzawa, K., and Kawamura, K.: Size distributions of dicarboxylic acids, ketoacids, ?-dicarbonyls, sugars, WSOC, OC, EC and inorganic ions in atmospheric particles over Northern Japan: implication for long-range transport of Siberian biomass burning and East Asian polluted aerosols, Atmos. Chem. Phys., 10, 5839-5858, doi:10.5194/acp-10-58392010, 2010.

Aggarwal, S. G. and Kawamura, K.: Carbonaceous and inorganic composition in long-range transported aerosols over northern Japan: Implication for aging of water-soluble organic fraction, Atmos. Environ., 43, 2532-2540, 2009.

Bzdek, B. R. and Johnston, M. V.: New particle formation and growth in the troposphere, Anal. Chem., 82, 7871-7878, 2010.

Cheung, H. C., Morawska, L., and Ristovski, Z. D.: Observation of new particle formation in subtropical urban Environment, Atmos. Chem. Phys., 11, 3823-3833, doi:10.5194/acp-11-38232011, 2011.

Clegg, S. L., Brimblecombe, P., and Wexler, A. S.: Thermodynamic model of the system $\mathrm{H}^{+}-\mathrm{NH}_{4}^{+}-\mathrm{Na}^{+}-\mathrm{SO}_{4}^{2-}-\mathrm{NO}_{3}^{-}-\mathrm{Cl}^{-}-\mathrm{H}_{2} \mathrm{O}$ at 298.15 K, J. Phys. Chem. A, 102, 2155-2171, 1998.

Draxler, R. R. and Rolph, G. D.: HYSPLIT (HYbrid Single-Particle Lagrangian Integrated Trajectory) Model access via NOAA ARL READY Website (http://www.arl.noaa.gov/HYSPLIT. php), NOAA Air Resources Laboratory, Silver Spring, MD, 2014.

Ehn, M., Petäjä, T., Aufmhoff, H., Hämeri, K., Arnold, F., Laaksonen, A., and Kulmala, M.: Hygroscopic properties of ultrafine aerosol particles in the boreal forest: diurnal variation, solubility and the influence of sulfuric acid, Atmos. Chem. Phys., 7, 211222, doi:10.5194/acp-7-211-2007, 2007.

Ehn, M., Thornton, J. A., Kleist, E., Sipilä, M., Junninen, H., Pullinen, I., Springer, M., Rubach, F., Tillmann, R., Lee, B., LopezHilfiker, F., Andres, S., Acir, I.-H., Rissanen, M., Jokinen, T., Schobesberger, S., Kangasluoma, J., Kontkanen, J., Nieminen, T., Kurtén, T., Nielsen, L. B., Jørgensen, S., Kjaergaard, H. G., Canagaratna, M., Dal Maso, M., Berndt, T., Petäjä, T., Wahner, A., Kerminen, V., Kulmala, M., Worsnop, D. R., Wildt, J, and Mentel, T. F.: A large source of low-volatility secondary organic aerosol, Nature, 506, 476-479, doi:10.1038/nature13032, 2014.

Gao, J., Wang, T., Zhou, X., Wu, W., and Wang, W.: Measurement of aerosol number size distributions in the Yangtze River delta in China: Formation and growth of particles under polluted conditions, Atmos. Environ., 43, 829-836, 2009.

Gysel, M., Weingartner, E., Nyeki, S., Paulsen, D., Baltensperger, U., Galambos, I., and Kiss, G.: Hygroscopic properties of watersoluble matter and humic-like organics in atmospheric fine aerosol, Atmos. Chem. Phys., 4, 35-50, doi:10.5194/acp-4-352004, 2004.

Hegg, D. A. and Baker, M. B.: Nucleation in the atmosphere, Rep. Prog. Phys., 72, 056801, doi:10.1088/0034-4885/72/5/056801, 2009.

Holmes, N. S.: A review of particle formation events and growth in the atmosphere in the various environments and discussion of mechanistic implications, Atmos. Environ., 41, 2183-2201, 2007.

Jung, J., Kim, Y. J., Aggarwal, S. G., and Kawamura, K.: Hygroscopic property of water-soluble organic-enriched aerosols in
Ulaanbaatar, Mongolia during the cold winter of 2007, Atmos. Environ., 45, 2722-2729, 2011.

Jung, J., Miyazaki, Y., and Kawamura, K.: Different characteristics of new particle formation between urban and deciduous forest sites in Northern Japan during the summers of 2010-2011, Atmos. Chem. Phys., 13, 51-68, doi:10.5194/acp-13-51-2013, 2013.

Kitamori, Y., Mochida, M., and Kawamura, K.: Assessment of the aerosol water content in urban atmospheric particles by the hygroscopic growth measurements in Sapporo, Japan, Atmos. Environ., 43, 3416-3423, 2009.

Kulmala, M., Vehkamäki, H., Petäjä, Dal Maso, T. M., Lauri, A., Kerminen, V.-M., Birmili, W., and McMurry, P. H.: Formation and growth rates of ultrafine atmospheric particles: a review of observations, J. Aerosol Sci., 35, 143-176, 2004.

Kulmala, M., Kontkanen, J., Junninen, H., Lehtipalo, K., Manninen, H. E., Nieminen, T., Petäjä, T., Sipilä, M., Schobesberger, S., Rantala, P., Franchin, A., Jokinen, T., Järvinen, E., Äijälä, M., Kangasluoma, J., Hakala, J., Aalto, P. P, Paasonen, P., Mikkilä, J., Vanhanen, J., Aalto, J., Hakola, H., Makkonen, U., Ruuskanen, T., Mauldin, R. L., Duplissy, J., Vehkamäki, H., Bäck, J., Kortelainen, A., Riipinen, I., Kúrten, T., Johnston, M. V. Smith, J. N., Ehn, M., Mentel, T. F., Lehtinen, K. E. J., Laaksonen, A., Keminen, V.-M., and Worsnop, D.: Direct observations of atmospheric aerosol nucleation. Science, 339, 943-946, doi:10.1126/science.1227385, 2013.

Kuwata, M., Kondo, Y., Mochida, M., Takegawa, N., and Kawamura, K.: Dependence of CCN activity of less volatile particles on the amount of coating observed in Tokyo, J. Geophys. Res., 112, D11207, doi:10.1029/2006JD007758, 2007.

Lee, J. Y. and Hildemann, L. M.: Surface tension of solutions containing dicarboxylic acids with ammonium sulfate, D-glucose, or humic acid, J. Aerosol Sci., 64, 94-102, 2013.

Metzger, A., Verheggen, B., Dommen, J., Duplissy, J., Prevot, A. S., Weingartner, E., Riipinen, I., Kulmala, M., Spracklen, D. V., Carslaw, K. S., and Baltensperger, U.: Evidence for the role of organics in aerosol particle formation under atmospheric conditions, P. Natl. Acad. Sci. USA, 107, 6646-6651, 2010.

Mochida, M. and Kawamura, K.: Hygroscopic properties of levoglucosan and related organic compounds characteristic to biomass burning aerosol particles, J. Geophys. Res., 109, D21202, doi:10.1029/2004JD004962, 2004.

Mochida, M., Miyakawa, T., Takegawa, N., Morino, Y., Kawamura, K., and Kondo, Y.: Significant alteration in the hygroscopic properties of urban aerosol particles by the secondary formation of organics, Geophys. Res. Lett., 35, L02804, doi:10.1029/2007GL031310, 2008.

Pavuluri, C. M., Kawamura, K., Uchida, M., Kondo, M., and Fu, P.: Enhanced modern carbon and biogenic organic tracers in Northeast Asian aerosols during spring/summer, J. Geophys. Res., 118, 2362-2371, doi:10.1002/jgrd.50244, 2013.

Ristovski, Z. D., Suni, T., Kulmala, M., Boy, M., Meyer, N. K., Duplissy, J., Turnipseed, A., Morawska, L., and Baltensperger, U.: The role of sulphates and organic vapours in growth of newly formed particles in a eucalypt forest, Atmos. Chem. Phys., 10, 2919-2926, doi:10.5194/acp-10-2919-2010, 2010.

Rolph, G. D.: Real-time Environmental Applications and Display sYstem (READY) Website (http://www.arl.noaa.gov/ready.php), NOAA Air Resources Laboratory, Silver Spring, MD, 2014. 
Saathoff, H., Naumann, K. H., Schnaiter, M., Schock, W., Mohler, O., Schurath, U., Weingartner, E., Gysel, M., and Baltensperger, $\mathrm{U}$.: Coating of soot and $\left(\mathrm{NH}_{4}\right)_{2} \mathrm{SO}_{4}$ particles by ozonolysis products of alpha-pinene, J. Aerosol Sci., 34, 1297-1321, 2003.

Salma, I., Ocskay, R., Varga, I., and Maenhaut, W.: Surface tension of atmospheric humic-like substances in connection with relaxation, dilution, and solution pH, J. Geophys, Res., 111, D23205, doi:10.1029/2005JD007015, 2006.

Seinfeld, J. H., Carmichael, G. R., Arimoto, R., Conant, W. C., Brechtel, F. J., Bates, T. S., Cahill, T. A., Clarke, A. D., Doherty, S. J., Flatau, P. J., Huebert, B. J., Kim, J., Markowicz, K. M., Quinn, P. K., Russell, L. M., Russell, P. B., Shimizu, A., Shinozuka, Y., Song, C. H., Tang, Y., Uno, I., Vogelmann, A. M., Weber, R. J., Woo, J. H., and Zhang, X. Y.: ACE-ASIA: Regional climatic and atmospheric chemical effects of Asian Dust and pollution, B. Am. Meteor. Soc., 85, 367-380, 2004.

Sjogren, S., Gysel, M., Weingartner, E., Alfarra, M. R., Duplissy, J., Cozic, J., Crosier, J., Coe, H., and Baltensperger, U.: Hygroscopicity of the submicrometer aerosol at the high-alpine site Jungfraujoch, $3580 \mathrm{~m}$ a.s.1., Switzerland, Atmos. Chem. Phys., 8, 5715-5729, doi:10.5194/acp-8-5717-2008, 2008.
Stohl, A.: Computation, accuracy and applications of trajectories: A review and bibliography, Atmos. Environ., 32, 947-966, 1998.

Varutbangkul, V., Brechtel, F. J., Bahreini, R., Ng, N. L., Keywood, M. D., Kroll, J. H., Flagan, R. C., Seinfeld, J. H., Lee, A., and Goldstein, A. H.: Hygroscopicity of secondary organic aerosols formed by oxidation of cycloalkenes, monoterpenes, sesquiterpenes, and related compounds, Atmos. Chem. Phys., 6, 23672388, doi:10.5194/acp-6-2367-2006, 2006.

Virkkula, A., Van Dingenen, R., Raes, F., and Hjorth, J.: Hygroscopic properties of aerosol formed by oxidation of limonene, alpha-pinene, and beta-pinene, J. Geophys. Res., 104, 35693579, 1999.

Yue, D. L., Hu, M., Zhang, R. Y., Wang, Z. B., Zheng, J., Wu, Z. J., Wiedensohler, A., He, L. Y., Huang, X. F., and Zhu, T.: The roles of sulfuric acid in new particle formation and growth in the mega-city of Beijing, Atmos. Chem. Phys., 10, 4953-4960, doi:10.5194/acp-10-4953-2010, 2010.

Zhang, R.: Getting to the critical nucleus of aerosol formation, Science, 328, 1366-1367, 2010.

Zhang, R., Khalizov, A., Wang, L., Hu, M., and Xu, W.: Nucleation and growth of nanoparticles in the atmosphere, Chem. Rev., 112, 1957-2011, 2012. 